\title{
PLANNING INSTRUMENTS AND URBAN DEVELOPMENT MANAGEMENT TOOLS FOR SMART CITIES. CASE STUDY: LUDWIGSBURG, GERMANY
}

\author{
P.-J. Sankowska ${ }^{1 *}$ \\ ${ }^{I}$ Department of Urban Planning, Faculty of Spatial and Environmental Planning, Technical University Kaiserslautern, \\ Pfaffenbergstraße 95, Geb. 1, D-67663 Kaiserslautern, Germany
}

\begin{abstract}
In recent years, the subject of digitalization has become an inseparable part of the urban development agenda, giving a promise of an effective and universal problem-solving tool in nearly every aspect of citizens' life. Based on broadly defined Information and Communication Technologies (ICT) it serves the demand for collaborative involvement of every stakeholder who wishes to participate in processes leading toward sustainable spatial transformation. However, the complexity of the urban environment and pace with which it develops are often not convergent with velocity and agility that this new dimension of city infrastructure is expected to deliver. As most public investments and political changes are highly convoluted from the legal side and relate to shared, long-term risks along with expenses covered from public funds, municipalities are often confronted with a problem of finding demand-corresponding, suitable planning, and management solutions on different administrative levels while assuring a secure and sustain agenda setting.
\end{abstract}

This paper presents a successful, working strategy in developing local, citizen-oriented planning and management instruments, despite the regional dependency and existing bureaucratic administrative system. The approach taken by the German city Ludwigsburg merges the classical idea of an integrated urban development concept with the innovatively restructured governmental body and results in a unique Integrated Sustainability Management System set together with citizens and third parties. The purpose of this case study is to show municipalities what resources and regulations are needed to set sustainable smart city goals, how to frame them into an iterative, participationoriented policy cycle and use them as effective management tools.

\section{Introduction}

The general attitude toward the smart city topic is ambivalent. From one side, the digitalization of cities is intended to benefit the governing units in more effective city management, resources distribution or civil control. On the other side, it may go with the cost of losing some of municipality's autonomy and independence in the decision-making process for the purpose of a better cooperation with other city stakeholders. Especially in countries where societies have a better understanding of influence options they have on their government, the increased demand on political transparency in smart city topic and bottom-up insistence on more collaborative involvement are visible. "What used to be a strictly top-down implementation of policy decisions, from the state down to society, is increasingly developing into a relationship in which governments have to use their capabilities and administrative power to react to organized elements of civil society" (Höchtl et al., 2015).

Such situation extorts on municipalities the development of innovative planning and management tools, which would be suitable for the local problematics and socio-economical profile. However, administrative structures often do not have enough human resources that would possess sufficient knowledge and experience to refrain their communal needs into smart city agenda (Bundesinstitut für Bau-, Stadt- und Raumforschung (German Federal Institute for Research on Building, Urban Affairs, and Spatial Development), BBSR, 2017). Subsequently, without a pragmatic, evidence-based approach in building an urban development concept focused on digital transformation, the governing body might not only be not able to correspond properly their efforts to existing public demand but also might lose the public trust in the long term. Therefore, analysing the already existing best practices and drawing concrete conclusions about them might be more helpful for municipalities and local communities than abstract, generalized guidelines.

Case study Ludwigsburg presents a successful and innovative approach toward using an already existing planning instrument, the German Integrated Urban Development Concept (Integriertes Stadtentwicklungskonzept; ISEK), to create an intersectoral, process-oriented, urban management tool, adapted into a legal framework and interlocked along all administrative levels. Long-term goals which result from previously set ISEK objectives are a base for eleven thematised masterplans which are collaboratively evaluated and updated each third year with all city actors during participation events called Future Workshops (Zukunfswerkstatt; ZuKo) (Stadt 
Ludwigsburg, 2018). In 2015 the city of Ludwigsburg put a considerable empathize on digital transformation and its influence on urban change, creating an innovation cluster LivingLaB to assist all city's actors in conducting smart cityrelated projects (Altmann, 2018).

This paper shows how a transparent and effective smart city agenda can be executed through pragmatic, integrated urban planning, certain governmental restructuration, and proper management tools. Section 3.1 explains how the European Leipzig Charter does from 2007 influence the sustainability of Ludwigsburg's ISEK. Section 3.2 shows the characteristic of this concept; it introduces the reader with the integration of ISEK into the governmental structure. Section 4 concentrates on ISEK Ludwigsburg and presents how certain municipal units were redesigned to enable pursuing the development goals. Section 5 presents the way how smart city topic is integrated into Ludwigsburg's development strategy and with which means it is executed. The conclusion section gives the reader a case study-based set of planning and management recommendations for setting a sustainable Smart City Agenda.

\subsection{Literature review}

The choice of the background literature of this case study was subordinated to the research methods, which are described in the greater detail in section 2. Theoretical sources introduce the reader with Leipzig Charter on Sustainable European Cities, standard structure of ISEK and ISEK-Ludwigsburg itself, which is perceived in Germany as one of the model examples of this planning method (Kurth, 2016). Main references are: the official Leipzig-Charter document; BBSR guidebook for communes on ISEK. Kurth' work focuses both on general characteristics on ISEK and ISEK-Ludwigsburg.

Literature which refers to the case study itself is focused mainly on municipality's reports, German Federal Association of Housing and Urban Development (Bundesverband für Wohnen und Stadtentwicklung e.V.,) journal issue "10 Years of Sustainable Urban Development in Ludwigsburg" ("10 Jahre Nachhaltige Stadtentwicklung in Ludwigsburg"), interviews, and local press notes.

\subsection{Research questions and hypothesis}

This paper focuses on answering the following research questions:

1. Which exact urban planning instruments are usually most effective in developing an integrated concept for local, spatial and socio-economic development?

2. Are there any benefits in merging the long-term, urban planning practice with city management?

3. Which values brings the integration of third parties into the planning and execution process?

4. Under which legal premises is it possible to maintain a secure and sustainable agenda setting for smart city topic?

5. What role does the smart city framework play in the urban development?
6. Is it necessary to place smart city topic in local agenda and if yes which tools are the most effective to do so?

Based on initial research and literature review, the author sets the following hypothesis: with the certain legal framework, planning instruments and management tools which correspond with commune's local, socio-economical profile, it is possible to create an efficient, executable and sustainable smart city agenda.

\section{Methodology}

This paper is based on a polymethodic research approach. First, the author sets a theoretical background using primary reference sources, which introduce the reader with three topics: (1) integrated urban development concept, the importance of its sustainability aspect and collaborative involvement element. This analysis presents the motivation of the German government to create ISEK, origin and main purpose of the concept, sustainability element (link to Leipzig Charter on Sustainable European Cities and German National Urban Development Policy (Nationale Stadtentwicklungspolitik)), its legal framework, structure and involved parties. The reader encounters that the inseparable part of this planning instrument is a complex participation process which needs to involve the third parties (citizens, companies, research units, NGO's, etc.) - upon this finding, the long-term benefits of a collaborative planning approach are shown. (2) Short description of Ludwigsburg. (3) ISEK Ludwigsburg. After providing sufficient, literature-based arguments, the importance of fitting this subject into spatial development agenda is shown. Secondly, an in-depth, empirical analysis of case study Ludwigsburg is conducted. Smart city focus is presented in the closing part.

Secondly, the author uses empirical research method, in form of a case study, answers the research questions, and confirms her hypothesis. As smart cities are a relatively new field of research (Dameri, 2016), there are not many reliable primary sources and academic publications which would allow a completely objective research analysis. As the official definition of a smart city and standardized measurement parameters of its performance are missing, a certain precaution in analysis needs to be taken (Dameri, 2016). The author also notices a possible problem with the subjectivity of municipality's reports on ISEK-Ludwigsburg, as although written by an independent governmental body, the decisions and final shape of involved strategies and projects still remains in hands of the municipal council and mayor that is chosen through political elections. In addition, the interest of private sector is also involved. Nevertheless, the benefits of chosen methods, that is, pragmatic analysis of best practice argued by theoretical background, refer primarily to its usability and applicable element, derived and summarized in the conclusion section. This case study is also the next reference, which will hopefully contribute to clarify the smart city term and define its exact performance parameters. 


\section{ISEK}

\subsection{Leipzig Charter on Sustainable European Cities}

European cities are often perceived as coherent and akin in their urban development, despite the notable differences in their spatial structure, historical background and socioeconomical profile (Le Galès, 2002). Although in the reality most cities vary extensively between each other (Haase, 2015), many of them share specific, mutual features that not only contribute to their overall image but also set important premises for their further transformation. The perception of European cities which have been shaped since Middle Ages corresponds in some extent with an idea of a sustainable, urban structure - the one that is compact, highly functional, socially diverse and inclusive (Sieber, 2004). According to World Commission (1987) in such space, a "sustainable development seeks the needs and aspirations of the present without compromising to meet those of the future". Therefore, to ensure sustainability-promoting development agenda, the goals like "compact, dense building substance; social and functional mixture; city-oriented mobility concepts; reinforcement of civic structures, climate-orientation, and energy efficiency" (Kurth, 2016) should be included in its setting.

Such an image of the city and its development was described in 2007 in Leipzig Charter on Sustainable European Cities and was shown as a role model and a goal in designing policies for balanced, urban development. The charter states that European cities, regardless their size, are valuable and irreplaceable economic, social and cultural goods and that spatial planning processes should incorporate all needed instruments to preserve and enhance their unique, local character (Deutsches Institut für Urbanistik (German Institute of Urban Affairs), 2012). In addition, it emphasizes the importance of solving socio-demographical problems, especially the challenges of social exclusion and necessity of integrating investive and noninvestive solutions into the local, regional and national development agenda (Bundesministerium für Verkehr, Bau und Stadtentwicklung (Federal Ministry of Transport, Building and Urban Development), 2007). The charter also obligates all Member States to adopt its presumption and is, therefore, one of the most important set of guidelines for city planning in Europe. According to the European Urban Knowledge Network (EUKN) (2017) the "integrated urban development policy entails that the spatial, sectoral and temporal aspects of key areas in urban policy are harmonized. The Leipzig Charter acknowledges that every level of government bears a specific responsibility for the future of our cities and regions".

In Germany, the Leipzig Charter is an inseparable part of the National Urban Development Policy (Nationale Stadtentwicklungspolitik) which "recommends the Integrated Urban Development Plan [ISEK] as a planning instrument" (Kurth, 2016) that assists the cities in their sustainable, spatial transformation. ISEK and its variations are used by German communes as an official document (despite its informal, nonobligatory character) in various ways, inter alia, as a longterm development strategy, a reference point in designing a local zoning plan or as a background required to apply for funding programmes according to German Building Code's (Baugesetzbuch; BauGB) (§§171a-171e BauGB) (BBRS, 2016).

\subsection{Characteristics, structure and stakeholders of ISEK}

The Integrated Urban Development Concept (Integriertes Stadtentwicklungskonzept) described in this paper as ISEK, is an informal planning method that concentrates on designing long-term goals and transforming them into a local development strategy - term "informal" in the German legal understanding means that this kind method is not an obligatory measure written in the national building law. ISEK focuses on transforming a concrete area ( $\$ 142 \mathrm{BauGB})$ within fixed time and financial frames ( $§ 149 \mathrm{BauGB})$. It must involve all city actors interested in the planning process and take under consideration the existing strategical conceptions, that is, district, city, regional and above-regional plans as well as current spatial and building law while composing development objectives (BBRS, 2016). ISEK merges planning and participative approaches in a way that assures sustainable corrections of existing urban deficiencies (städtebauliche Missstände; §136(1)-(3) BauGB) and fulfils commune's and sinus milieu's needs. The combination of such deductiveinductive proceeding includes sectoral expertise $(\S \S 140-141$ BauGB) and open participation processes $(\S 137$ BauGB) that results in a strategy which spatializes commonly set objectives based on in-depth planning and situational analysis (see Figure 1$)(\S 171 \mathrm{~b}(2)$ BauGB). ISEK results in graphical and text documentation (Kurth, 2016).

\section{Figure 1 Deductive-inductive character of ISEK}

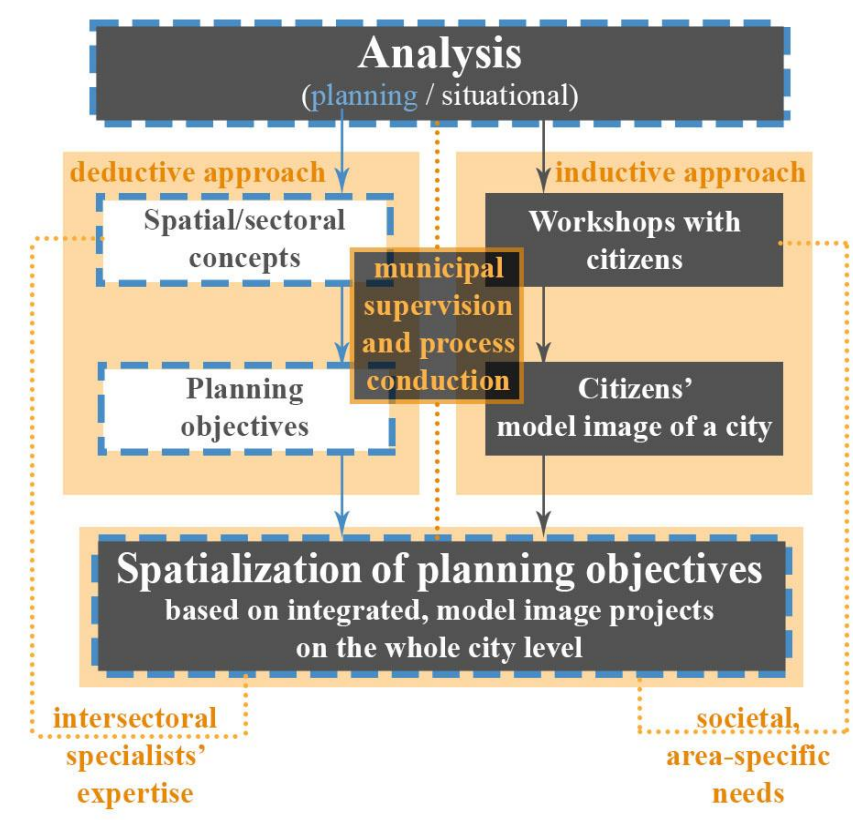

The core idea of ISEK is to create a solid basis for effective collaboration between third parties and municipality (see Figure 2). According to Kurth (2016), "the necessary prerequisites of such urban development process are clear, 
political backing from the mayor and municipal council, an open discussion culture, a resource-efficient approach and procedural, flexible strategy". Such agenda formulation also enables finding consensus in pooling public and private funds (BBRS, 2016), which is required, inter alia, in revitalizing façades of private buildings or in creating public squares which may overlay with private plots. EUKN (2017) emphasizes that „to deal effectively with such parallel responsibilities, the coordination between different sectoral policies should be improved, while keeping in mind temporal and spatial aspects of urban development policies".

Figure 2 ISEK stakeholders

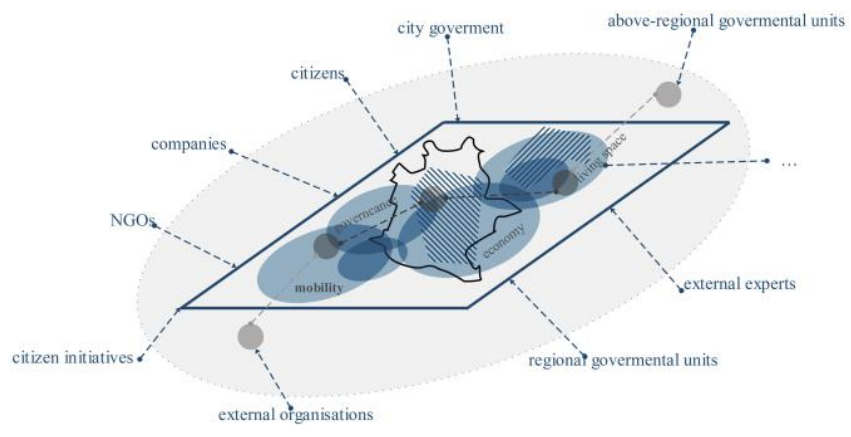

\subsubsection{ISEK Financing models}

The concepts like ISEK can be financed in Germany either from commune's household or through a mixed method ( $\S 164 a-164 b$ BauGB), involving municipality's financial resources and national and/or federal state funding programmes which are listed in German Building Code. Funds from the federal government cover up to $66 \%$ of the whole investment's costs, whereas the commune is obligated to provide the rest of the sum, which can be covered either by city's reserves or from a loan (BBSR, 2016).

\subsection{Interim conclusion}

ISEK is a flexible, area-specific planning instrument, which gives municipalities and citizens a chance to take an active role in the collaborative development of their shared, urban space. Through its local focus, it provides a solid background for designing concrete answers to existing problems and public demand. It serves as a transparent communication tool, enhancing the quality of both planning and execution processes (BBSR, 2016).

As ISEK needs to be prepared concerning specific, local situation, there is no one, uniform way of setting the planning objectives that would correspond to every communal problem (BBSR, 2016). However, few important elements should be incorporated into the process of ISEK's establishment:

- "spatial levels (region, city, sub-regions),

- departments (construction, housing, economy, traffic, environment, social, culture et al),

- stakeholder (administration, local affairs, corporations, citizens et al.),

- $\quad$ formal and informal planning tools (..),
- different financing options (municipal budget resources, supplementary allowances, private financing)".

\section{ISEK Ludwigsburg}

\subsection{Image of the city Ludwigsburg}

Ludwigsburg is an average in size and population Swabian city, located in the south-west Germany, in the federal state (Bundesland) Baden-Württemberg. It belongs to the metropolitan area of the city of Stuttgart that makes it to some extend depended on the state capital from legal and economic perspective. Ludwigsburg is divided into twelve districts where live 93,593 people (31.12.2017, Statistisches Landesamt Baden-Württemberg (Federal State Statistical Office BadenWürttemberg), 2018). Its average density equals $2,200 / \mathrm{km}^{2}$ $(5,600 /$ sq. mi). The city's vibrant, historical centre is very dense, especially in comparison to other German towns, and equals $5,578 / \mathrm{km}^{2}(14,199 / \mathrm{sq}$. mi).

The current image of the city is based on three spatially varying identities that derived in different historical periods. 1. A residential, baroque planned town from the eighteenth century composing today's city centre; 2. A historical garrison city from nineteenth century; 3 . An industrial town from twentieth century with a strong economic structure that remained its garrison function to host the US Alliance army after 1949. After reunification of Europe in 1990 that brought the great structural change and triggered the withdrawal of foreign forces, Ludwigsburg lost its important garrison function and was forced once again to find its identity both from an economic and social perspective. The politicians and the municipality needed to work on cresting a sustainable, longterm solution to support the city and its citizens in the times of change (Kurth, 2016).

Therefore, since many years the government of Ludwigsburg and the local community have been working on differentiating city's character through incorporating new policies and spatial concepts, which through their collaborative and inclusive character would support the city in developing a new, democracy-oriented identity, and to find a room for more autonomous, local growth (Spec, 2010).

\subsection{ISEK Ludwigsburg}

Ludwigsburg's current development strategy is a result of long-term cooperation between the municipality and third parties that has started in 2004 when the first impulse for ISEK was set. The city has shaped its own, specific planning and management cycle which enables fulfilling the objectives and strategical goals that would be relevant for Ludwigsburg's transformation. According to SLB RNS (2018), the approach taken by the city "(..) is confirmed through the Leipzig Charter on Sustainable European Cities from 2007 and corresponds with German National Urban Development Policy (..) [and it] supports the implementation of objectives like "city of social balance", "city of short distances" or "climate-oriented city" (..)". 


\subsubsection{Municipal department structure in Ludwigsburg}

Ludwigsburg is known for its unique, municipal structure that was transformed to enable more agile and effective coordination and conduction of ISEK strategical goals. The success of this transformation made the city government one of the most innovation-opened in Germany. In 2014 it became a prestige sustainability prize (Nachhaltigkeitspreis) in "city and commune" (Städte und Gemeinden) category for "its excellent performance in coping with environmental and social, future challenges" (Ludwigsburg.de, 2014). In May 2018, Ludwigsburg together with three other cities and one districts' association was awarded to a federal state's funding programme called "digital future commune@BadenWürttemberg” (Digitale Zukunftskommune@bw). The city was given $880.000 €$ to develop its on-going and planned projects that would help it in becoming a smart, connected city through pursuing goal from the local Digital Agenda (Ludwigsburg.de, 2018).

Werner Spec, the current, independent mayor of Ludwigsburg, who has been holding his office since 2003, initiated the restructuration of a municipal body in 2008. Four years after introducing ISEK it was clear that without a specific structure within the local government, many of the ideas or proposed projects, collaboratively established with Ludwigsburg's community, were not able to be executed as desired. Therefore Spec (2016) came to the conclusion that ISEK as a "(..) the comprehensive form of cooperation requires an active management and coordination".

In 2008 the municipality created an additional Department Unit, Sustainable Urban Development (Referat für Nachhaltige Stadtentwicklung) (RNS), which was directly subordinated to the mayor and municipal council, and which overtook all ISEK-related tasks. From now on ISEK has transitioned from a single planning method to city's formal, urban management system. RNS was therefore given a cross-sectoral function (Querrschnittsfunktion), meaning that it needs to coordinate its work with every department and vice versa (Kurth, 2016). The next important element of Ludwigsburg's ISEK-oriented governmental structure is a municipal council. It "is, through voting legitimized, political committee represented by the citizens. It is responsible for advisory and decision on resources, projects and expenditure of commune's household" (SLB RNS, 2018). Council, therefore, decides which part of the development concept will be finally executed. Thus, it is important to involve it in every ISEK-related process, including ZuKos, to assure a good communication and understanding of each urban matter and to maintain an efficient cooperation between the municipality, council, and citizens (SLB RNS, 2018).

\subsubsection{Characteristics and components of ISEK Ludwigsburg}

The Integrated Urban Development Concept is used in Ludwigsburg as both a planning instrument and an urban development management tool. Its first function concentrates on urbanism-related matters and contains components like participation events called Future Workshops (Zukunftskonferenzen) (ZuKo), eleven, categorized masterplans (Masterpläne), Integrated District Development Concepts (Stadtteilentwicklungskonzepte) (STEP), and means for active, civic involvement (Kurth, 2016).

Figure 3 Municipal department structure, Ludwigsburg

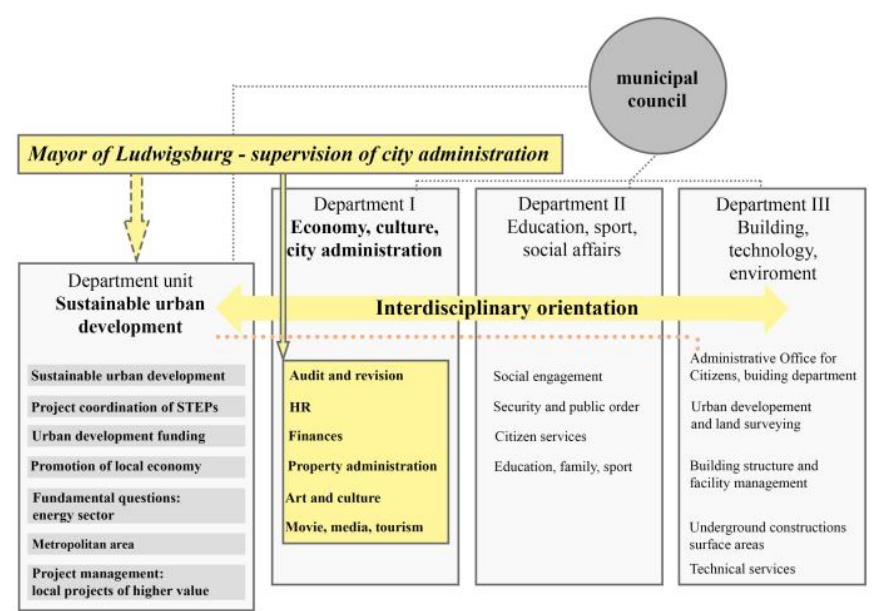

Its second use supports the city in coordinating the undertaken actions and executing them with diverse stakeholders. It is also used as a sustainable policy cycle that is based on a specific controlling tool that uses 64 indicators (Indikatioren) to evaluate the overall development progress. ISEK is therefore not a single spatial plan but a complex set of above-listed elements and serves the city as an Integrated Sustainability Management (Integriertes Stadtentwicklungspolitik) with a firm management cycle (Managementkreislauf). This use together with masterplans are especially important in fulfilling the goals of city's Digital Agenda.

The planning process started in 2004 with an internal discussion regarding the choice of urban development instrument, which would serve the city demand on more integrated and inclusive spatial transformation, and supporting its long-term strategy. The debate resulted in the formulation of ISEK's first thematic areas (sectors) and a general idea of the participative character of the whole process (BBSR, 2016). After the internal session, the first debate with citizens was organized to gather all, most important impulses for urban agenda setting.

In 2006, after the foundation phase was conducted in 2005, the first two ZuKos took place and resulted in setting Ludwigsburg's first ISEK (SLB RNS, 2018). The above listed, marked bold elements of ISEK are described in greater detail below.

ZuKos are two-day workshops organized by the municipality which are open for everyone and which main aim is to develop "visions, goals, and ideas of projects for next ten to twenty years" (SLB RNS, 2018). Up until 2018, over 1.250 participants took part in this event, representing diverse 
affiliation spectrum: from citizens from every social class, ethnic background and age groups, through diverse companies, universities, activists, and politicians.

SLB RNS (2018) emphasizes, "the [main] goal it to constructively, openly but also controversially discuss the future of the city in changing groups. This special spirit of ZuKo was already visible in the past: people with a different background that had never had anything to do with each other, brought together their skills, experience, and engagement. It brings many social groups together. (..) Everyone is equal".

Spec (2015) notices that ZuKos bring "a big enrichment to [municipality's] conception work (..) and decision-making processes". The detailed evaluation and documentation of $\mathrm{ZuKos}$ is an official basis for municipal council in decision and change-adaptation process of ISEK and its thematic areas (Spec, 2010).

In 2008 the mayor of Ludwigsburg together with the municipal council, decided to categorize all objectives from ISEK, transform them into strategical goals and subordinate them into eleven masterplans which contain diverse projects and execution measures, specific for each thematic area (1. attractive housing, 2. economy and work, 3. mobility, 4. social and generational inclusion, 5. energy, 6. education and care, 7. culture, 8. green city, 9. liveable inner city, 10. vital districts, 11. sport and health) (SLB RNS, 2018). Each of them is managed through Communal Management Information System (Kommunales Steuerungs- und Informationssystem (KSIS) by an executive that coordinates the implementation of each, single project. The executives are also responsible for the evaluation of execution measures, continuation of masterplans and regular reporting of their status to the mayor, municipal council and department unit RNS (SLB RNS, 2018). KSIS is described in the greater detail in 4.2.3.

The Integrated District Development Concepts were introduced in 2008 as a concretization of ISEK's and masterplans' objectives on specific city districts. STEPs are plans based on a strengths-weaknesses analysis that focus on micro-local development strategy that is designed with the district's community, activists' group and responsible for this area municipal unit. The main purpose of those long-term concepts it to fulfil the current needs and problems of local sinus-milieus. Therefore, STEPs are discussed in three to five years sequence on district's ZuKos - after which they are updated and prolonged according to the workshops' results.

The process-progression is, as in the case of ISEK, evaluated using indicators and carefully documented (SLB RNS, 2018). The municipal council passed the first set of indicators in 25 th March 2009 as a monitoring and controlling instrument of results and process-progression of ISEK and STEPs. 64 gauges serve as "(..) quantitative and qualitative (..) control" (SLB
RNS, 2018) for responsible and efficient management of the city's household.

Based on above described ISEK's elements, the commune has created a unique planning instrument and an agile management tool that together compose so-called Integrated Sustainable Management (management cycle) (Integriertes Nachhaltigkeitsmanagement (Managementkreislauf)). This repetitive, five-step process defines firm execution steps and their relation with ISEK's specific components. The management cycle through its fixed, simple structure, assures a transparent insight into commune's investments, and development plans. According to SLB RNS (2018), its steps are "1. Analysis of the current, local situation, 2. Further development of strategical goals, 3. [Municipal council] passes [collaboratively selected] goals and objectives, 4. Execution of objectives and goals via ISEK, 5. [Controlling], reporting and evaluation".

\section{Figure 4 Chronological development of ISEK LB}

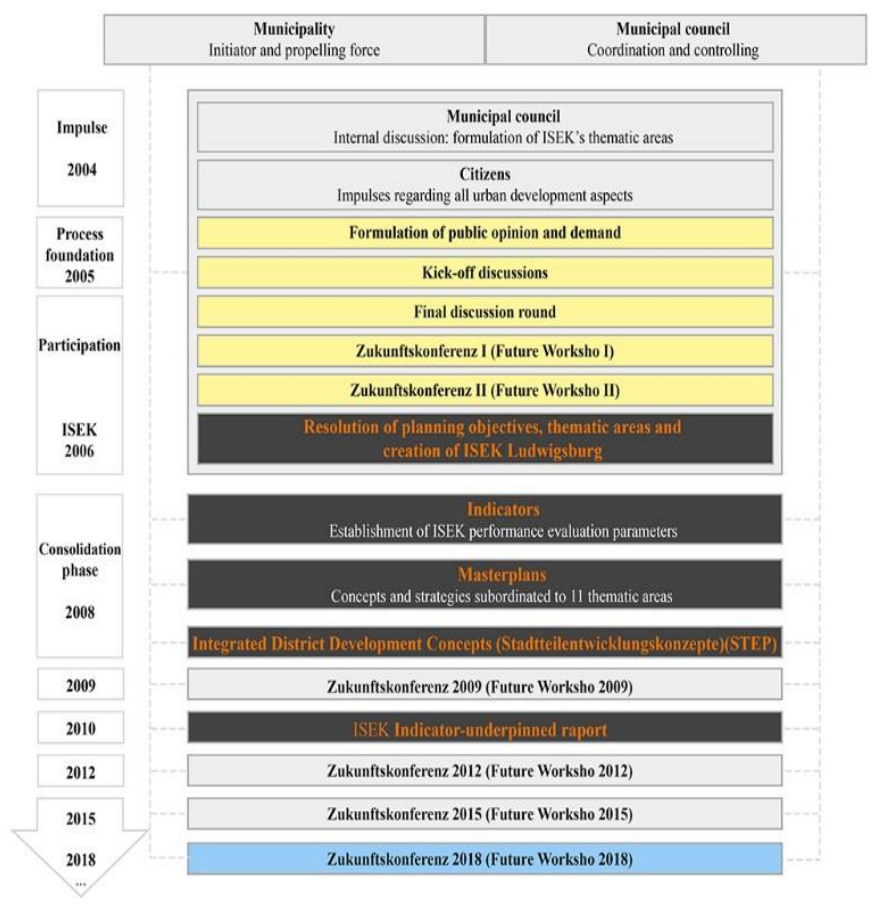

\subsubsection{Communal Management Information System (KSIS)}

KSIS system is the first urban controlling and information system in Germany (June 2018) which supports the commune in execution of projects subordinated to eleven masterplans from ISEK. It is a web-based platform that displays the past and on-going public undertakings together with their budged and stakeholders, and enables the direct participation of interested parties like citizens, companies, etc. in the planning and/or executive process (SLB RNS, 2018). KSIS “connects projects with city's household numbers, data from investment 
controlling and indicators from ISEK" (KSISLudwigsburg.de, 2019).

KSIS also is one of the main instruments in Ludwigsburg's municipality that enables pursuing the goals of the local Digital Agenda. "It is planned that in the near future eleven masterplans will be connected with KSIS through geographic information system (GIS)" (KSIS-Ludwigsburg.de, 2019) to bring more velocity and enable better project coordination.

\section{Smart City Ludwigsburg}

Digitalization subject has been present in Ludwigsburg's development agenda since 2015 when, upon the results of the fifth $\mathrm{ZuKo}$, it became one of the main objectives for city's further, sustainable transformation. "Digitization increases accordingly to the growing connectivity between energy, mobility, Information Technology (IT), building technology and security segments - (..) the borders between those segments dissolve and from a sustainability perspective they should be connected together. (..) The issue lays in the fact that the [current] structures within and between [public] organizations [involved in the digitalization process] portray this crosssectoral approach in a very limited way. Therefore, the substantial success factor of the way to the Smart City lays in the process of implementing the solutions that aim for connected, paramount subjects and that not only opt for one segment or single product" (Bräuning, 2017). Therefore, in 2015 the municipal representatives together with the citizens designed a vision of Ludwigsburg as a Smart City, called Ludwigsburg 2030+, setting "Digitalization, participation and the city" as a development premise (Ludwigsburg.de, 18.05.2017).

\subsection{Elements of Smart City Ludwigsburg}

The elements of the digital city that Ludwigsburg pursues can be sub-categorised into four groups: strategy, legislation, supervision/execution, and intersectoral communication. Each of the elements is connected to ISEK in a specific way, described in the pointed chapter. The first element is embodied in form of a Digital Agenda Ludwigsburg (DA LB) (chapter 5.1.1) which sets the general direction and premises of city's digital transformation. It is also city's planning instrument in a sense of strategy design. The second, legislation, refers to the strong anchor of mayor and the municipal council into the evaluation and decision-making process DA LB-related undertakings - this legislative body reaches the final resolution on resources, collaboration partners and projects that should be brought into the DA LB concerning current household capacity and the agenda's objectives. Supervision and execution of the projects and collaborations are conducted by Digitalization's Controlling Group (chapter 5.1.1) together with a special municipal unit Innovation Network LivingLab (chapter 5.1.2) which bonds the public and private sectors together, securing the interests of all parties involved in the digital transformation. Intersectoral communication is pursued through the KSIS system (chapter 4.2.3). As this paper aims to present the general policy behind pursuing the Smart City agenda and shows specific planning instruments and implemented urban management tools, the description of single, specific projects is limited to three, shorty described examples at the end of this chapter.

\subsubsection{Digital Agenda Ludwigsburg}

Digital Agenda Ludwigsburg is Ludwigsburg's strategy on becoming a Smart City, created in 2015 and supervised by digitalization's controlling group (see paragraphs: DA LB roof strategy and digitalization's controlling group). It is a set of directions and objectives that correspond with the digital strategy of the federal state Baden-Württemberg called “digital@bw" (Digitalisierungsstrategie “digital@bw" des Landes Baden-Württemberg) (digital-bw.de, 2017). The DA LB is a part of ISEK and its eleven masterplans. According to Spec (18.05.2017) "the DA LB is a guideline for our city that summarizes how the local digitalization subjects will be approached", in order to organize and mindfully steer the influence it has on every part of urban space and socioeconomic matters, ensuring bringing a new quality of living. DA LB is Ludwigsburg's intention to assure a comfortable, inclusive and secure urban coexistence of all stakeholders through digital means (SLB RNS, 2018) which are embodied through projects subordinated to a specific masterplan. DA LB objectives are under constant monitoring and evaluation procedure which in a way is similar to the management cycle it is undertaken a repetitive, participation-based process which concentrates on adjusting the present strategical goals and planning objectives to the current needs and general, global challenges.

\section{$D A$ LB roof strategy}

DA LB's concrete structure and character was shaped in 2017 together with MHP, a Porsche company, in a form of a roof strategy (das Dach für die Strategie) to organize Smart City element (see Figure 5). The roof strategy is symbolically set on three pillars: users (meaning all city actors), processes and data. Each of the pillars represent different sphere of action, different goals and specific execution methodology: users' embodies stakeholder-oriented investments in economy, media and housing sector that enhance the quality of life in Ludwigsburg through digital measures; processes maintain effective and synergy-oriented flow of project conduction; data assist regulation of infrastructure's utilization load. All pillars, meaning all projects and processes, are operated on municipality's Smart City Cloud, technical infrastructure (Digital Infrastructure) for Smart Cities. The whole structure is protected by city's IT security system (Fraunhofer IAO, 2017).

\section{Digitalization's controlling group}

Since 2017, the so-called Digitalization's Controlling Group (DCG) (Lenkungsgruppe Digitalisierung) which is a part of Ludwigsburg's municipality has led the general supervision of Smart City related undertakings. It coordinates the on-going projects from informative, legislative and execution perspective - it enables the execution of further process phases and decides which projects should be involved in DA LB for 
transforming Ludwigsburg into a smart, connected city (SLB RNS, 2018). In October 2018, the city chose a Chief Digital Officer for the new, digitalization team to work on further development of DA LB (Altmann, 2018). The current spectrum of subjects ranges from e-Governance, mobility, public space to energy and grows with every additional project. In Ludwigsburg's economy report, Altmann (2018) emphasizes that "the focus lays in implementing "quick-win", lowthreshold projects that would bring an instant added value" in order to crystallize a certain proceeding methodology which would be transparent and approachable for all city stakeholders. All undertaken actions will be funded from diverse, national funding programmes and are planned to be accomplished between 2019 and 2021. One of them, an Interior Ministry programme "Cities and communes 4.0 (Städte und Gemeinden 4.0) - Future Communities" conferred to Ludwigsburg its highest funding of $100.000 €$ (Bräuning, 2017).

Figure 5 Digital Agenda of Ludwigsburg, roof strategy

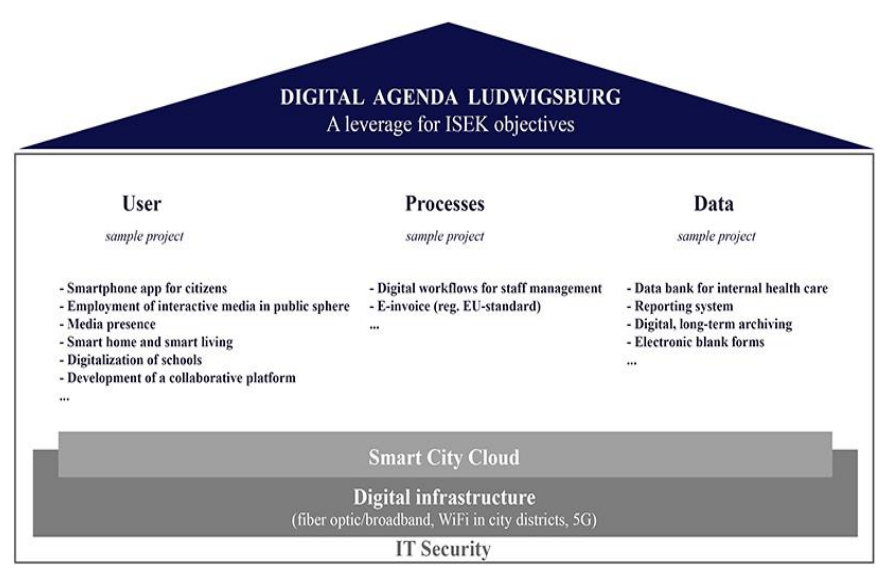

\subsubsection{Innovation Network LivingLaB}

In 2015, the municipality together with Mayor Werner Spec formed a special branch office called Innovation Network LivingLaB (Geschäftsstelle Innovationsnetzwerk LivingLaB). The Living Lab's lead, Bräuning (2017) says, "the branch office creates ideas, solutions, services, and business models that are then developed and tested as pilot projects to make them market-ready. Those solutions support pursuing the strategical goals and objectives of ISEK" and are incorporated into the masterplans and ipso facto into the city space itself. In contrary to DCG, the LivingLaB concentrates on specific, often experimental, projects and not on a general digital agenda setting and big picture strategy. In practice, LivingLaB has two core functions: firstly, it serves as a city laboratory (Stadtlabor) and offers the space and funding possibilities to develop diverse digitalization-related ideas (see the paragraph below); secondly, it works as an "open innovation network" (Stadt Ludwigsburg, 2018), a cluster that connects representatives from diverse sectors like economy, research, politics or private companies that work on ISEK masterplans' related projects. According to Fraunhofer (2017) such active collaboration between private and public segment is exceptional in Europe, making Ludwigsburg from one side a role model commune from the European perspective. From the other, the branch office secures the core idea of ISEK on sustainability, the German National Urban Development Policy and therefore the Leipzig's Charter guidelines. Subsequently, LivingLaB as a governmental unit serves the municipality as an urban management tool to conduct the work on Smart City related subjects and pursue the objectives of DA LB.

\section{Stadtlabor}

In 2017, using funds from award received in the national commune competition Future City (Zukunftsstadt) which was organized by the Federal Ministry for Education and Research (Bundesministerium für Bildung und Forschung), Ludwigsburg created a co-working and co-innovation space, (Bräuning, 2017). In such an innovation-oriented environment, the city organizes numerous events, which invite every interested party into creating smart city-related new ideas. In this mean city holds so their Makeathons, short, intensive, moderated workshops where citizens together with representatives from research units, municipality, private companies and NGOs work on concepts, build prototypes, and test them in the real urban space (Stuttgarter Zeitung, 01.10.2017). Innovation Network LivingLaB uses also the city laboratory to work with the civic community on solutions to answer the inhabitants' current needs. In this regard, citizens together with cluster's workers can, for example, build and install the air quality sensors, discuss mobility challenges and sketch solution-oriented ideas (Bräuning, 2017).

Following projects are some of many which were undertaken in Ludwigsburg as a result of Innovation Network LivingLaB:

- Intelligent dustbin - collaboration in time spam of May-December 2018 between Start-up Binando and municipal specialist field Technical Services (Fachbereich Technische Dienste) that analyses through ultrasound sensors the fill level of dustbins and shows which of them should be made empty. Designed as a smartphone application, it provides the communal cleaning team with the optimal route to full bins that calculated to achieve more time efficiency and reduce more $\mathrm{CO} 2$ emission. So generated data were then sent to Ludwigsburg's Smart City Cloud (SCC) (LivingLaB, 2018).

- $\quad$ Flood Monitoring System (FMS) - FMS is a camera and ultrasound sensor based monitoring and alarming system designed by Bosch and LivingLaB that analyses the water level, character of its flow, and its speed. The Data are sent to Bosch IoT Cloud and SCC. If one of the critical limits is reached, the short text message to the municipal and to affected habitants is automatically sent (LivingLaB, 2018).

- $\quad$ ParkingSpotters (PS) - PS is a sensor-based parking management system designed and constructed by Department of Public Services (Stadtwerke Ludwigsburg) and MHP (LivingLaB, 218). 


\section{Conclusion}

Ludwigsburg is an example of a city that transformed a single planning method into a powerful, urban development tool, giving itself a chance to find its new identity in the digital era. An ambitious and consequent municipal representative used the sustainable and inclusive character of ISEK Ludwigsburg to create a long-term development strategy that would be agile and uniform enough to cope with diverse, urban challenges regarding every city sector and time frame. The concept bonds the local community as well as private and research sector into every step of agenda setting, securing the interest of all city actor and strengthening the sense of civic responsibility.

ISEK with all its facets is coordinated and executed by an innovative Department Unit for Sustainable Urban Development, which brings the uncommon ideas into the daytime practice of the city's government. Thank such approach, the city has become a national and international example for its integrated urban development approach and its innovative, collaboration-oriented planning and management instruments.

Bräuning (2017) states that this interest is visible "through an increasing number of [consulting] inquiries from administrative, political, economy and research sector, as well as from interviews request from press and from the conference invitations. Although the city of Ludwigsburg, with its less than 100.000 citizens, does not belong to the "biggest and most renowned [cities in the world]", with its LivingLaB it became a European leader in co-innovative, integrated urban development (..) [a fact] that was confirmed in benchmark study from Fraunhofer IAO".

Based on this study, the author summarized the most important planning and management recommendations for setting the Smart City Agenda:

- $\quad$ analysis of local identity, strengths, weaknesses, needs and challenges from micro and macro perspective,

- recognition of national and global challenges,

- analysis and selection of existing planning methods,

- incorporation of integrated urban development concept or its sustainable, inclusive character into the local digitalization strategy,

- well-thought policy cycle which enables an intersectoral participation and non-governmental expertise,

- creation of an independent, governmental unit which has a legal power to work directly and autonomously,

- set of development priorities based on resources, funding options, regional and above-regional competition,

- establishment of a local innovation network which gathers research units, experts and private sector,

- consequence, flexibility, political neutrality, openness.

\section{References}

Altmann O (2018) Auf dem Weg zur smarten Stadt. Die Digitale Agenda der Stadt Ludwigsburg (On the Way to a Smart City. Ludwigsburg's Digital Agenda). Wirtschaftsbrief (economy report), (3) 2018, Stadt Ludwigsburg Referat Nachhaltige Stadtentwicklung/Wirtschaftsförderung (City of Ludwigsburg Department Unit for Sustainable Urban Development/Local Economy Promotion), Ludwigsburg, Germany, p. 6.

Bräuning A (2017) Das Living LaB Ludwigsburg ist eine europaweit einmalige Konstellation (LivingLaB Ludwigsbur is a unique constellation Europe-wide). Magazin aktuell (Magazine Current) (4) 2017. vbw Verband badenwürttembergischer Wohnungs- und Immobilienunternehmen e.V. (vbw Association of baden-württemberg Housing and Real Estate Companies), Stuttgart, Germany, pp. 6-8.

Bundesinstitut für Bau-, Stadt- und Raumforschung (Federal Institute for Research on Building, Urban Affairs and Spatial Development) (BBSR) (2016) Integrierte städtebauliche Entwicklungskonzepte in der Städtebauförderung. Eine Arbeitshilfe für Kommunen (Integrated Urban Development Concepts. A Guidebook for the Communes).

Bundesministerium für Umwelt, Naturschutz, Bau und Reaktorsicherheit (Federal Ministry of the Environment, Nature Conservation and Nuclear Safety), Bonn, Germany.

Bundesinstitut für Bau-, Stadt- und Raumforschung (Federal Institute for Research on Building, Urban Affairs and Spatial Development) (BBSR) (2018)

https://www.bbsr.bund.de/BBSR/EN/RP/GeneralDepartmenta 1Research/UrbanDevelopment/ISEK/01_Start_dossier.html?d ocId=565104\&notFirst=true (accessed 31/12/2018).

Bundesministerium für Verkehr, Bau und Stadtentwicklung (Federal Ministry of Transport, Building and Urban Development) (BMVBS) (2007) Leipzig Charta (The Leipzig Charter on Sustainable Urban Development).

Dameri RP (2016) Smart City Implementation. Creating Economic and Public Value in Innovative Urban Systems. Springer Nature, Cham, Switzerland.

Deutsches Institut für Urbanistik (German Institute of Urban Affairs) (2012) https://www.nationale-

stadtentwicklungspolitik.de/NSP/SharedDocs/Publikationen/ EN/leipzigcharta_en.pdf? _ blob $=$ publicationFile \& $=1$ (accessed 31/12/2018).

Digital BW (2017) https://www.digitalbw.de/digitalisierungsstrategie? redirect $=\% 2 \mathrm{~F}$ -

\%2F20170712_news3rahmen_stadtderzukunft (accessed 09/01/2019).

European Urban Knowledge Network (EUKN) (2017) 10 Years after the Leipzig Charter. Bundesinstitut für Bau-, Stadt- und Raumforschung (Federal Institute for Research on Building, Urban Affairs and Spatial Development), Bonn, Germany.

Firges J, Melenk H (1980) Ludwigsburg: Der Weg von der Residenzstadt zur mittleren Industrie- und Handelsstadt (Ludwigsburg: The Approach of a Residential [Baroque] City 
to Middle-size Industrial and Trade City). Kulturamt Ludwigsburg, Ludwigsburg, Germany.

Frauenhofer IAO (2017) https://www.iao.fraunhofer.de/langde/presse-und-medien/aktuelles/1841-ludwigsburgdigital.html (accessed 12/01/2019).

Le Galès P (2002) European cities. Social conflicts and governanvce. Oxford University Press, Oxford, UK.

Haase A (2015) European cities between shrinkage and regrowth - current trend and future challenges. In University, Society, Industry, Band 4 (Volume 4) - die Stadt der Zukunft. Aktuelle Trends und zukünftige Herausforderungen (The City of Future. Current trend and future challenges). Waxmann Verlag GmbH, Münster, Germany.

Höchtl J et al. (2015) Big Data in the Policy Cycle: Policy Decision in Making in the Digital Era. Journal of Organizational Computing and Electronic Commerce, Volume 26 (1-2), pp. 147-169.

KSIS-Ludwigsburg.de (2019) https://ksis-ludwigsburg.de/ (accessed 10/01/2019)

Kurth D (2016) Nachhaltige Planstadt Ludwigsburg

(Sustainable Planned City Ludwigsburg). 10 Jahre

Nachhaltige Stadtentwicklung in Ludwigsburg (10 Years

Sustainable Urban Development in Ludwisgburg). vhw -

Bundesverband fur Wohnen und Stadtentwicklung e.V. (vhw

- Federal Association of Housing and Urban Planning),

Berlin, Germany, pp. 29-34.

LivingLaB (2018)

https://www.ludwigsburg.de/site/Ludwigsburg-

Internet/node/11509214/Lde?QUERYSTRING=livinglab

(accessed 13/01/2019).

Ludwigsburg.de (2014)

https://www.ludwigsburg.de/,Lde/start/stadt_buerger/Deutsch er+Nachhaltigkeitspreis+2014.html (accessed 02/01/2019)

Ludwigsburg.de (18.05.2017)

https://www.ludwigsburg.de/,Lde/start/stadt_buerger/Wettbew erb+Zukunftsstadt.html (accessed 12/01/2019).

Ludwigsburg.de (2018)

https://www.ludwigsburg.de/,Lde/start/stadt_buerger/digitale+ zukunfskommune.html (accessed 12/01/2019).

Siebel W (2004) The European city (Die Europaische Stadt). Walter Siebel/Suhrkamp, Frankfurt am Main, Germany

Spec W (2010) Konzept: Chancen fur Ludwigsburg. Eine Kommune auf dem Weg zur nachhaltigen Stadtentwicklung (Chances for Ludwigsburg. A Commune on its Way to Sustainable Urban Development). Planerin (2) 2010, SRLVereinigung für Stadt-, Regional- und Landesplanung e.V. (SRL-Association of City, Regional and National Planning), Berlin, Germany, pp. 25-28.

Spec W (2016) Der Ludwigsburger Weg - Wir stellen der Zukunft keine Rechnung (The Ludwisgburg Way - We Don't Charge the Future) 10 Jahre Nachhaltige Stadtentwicklung in Ludwigsburg (10 Years Sustainable Urban Development in Ludwisgburg). vhw - Bundesverband fur Wohnen und Stadtentwicklung e.V. (vhw - Federal Association of Housing and Urban Planning), Berlin, Germany, pp. 7-12.
Spec W (18.05.2017)

https://www.ludwigsburg.de/,Lde/start/stadt_buerger/Wettbew erb+Zukunftsstadt.html (accessed 12/01/2019).

Stadt Ludwigsburg Referat für Nachhaltige Stadtentwicklung (Ludwigsburg Municipality, Department Unit for Sustainable Urban Development) (RNS) (2018) Zukunfstkonferenz 2018. Indikatorengestützter Bericht zur Nachhaltigen Stadtentwicklung (Future Workshop 2018. Indication-based Report Regarding Sustainable Urban Development). Stadt Ludwigsburg Referat für Nachhaltige Stadtentwicklung, Ludwigsburg, Germany.

Statistisches Landesamt Baden-Württemberg (Federal State

Statistical Office Baden-Württemberg) (2018)

https://www.statistik-

bw.de/BevoelkGebiet/Bevoelkerung/01515020.tab?R=GS118 048 (accessed 05/01/2019).

Sting A (2000) Geschichte der Stadt Ludwigsburg I. Von der Vorgeschichte bis zum Jahr 1816 (History of city of Ludwigsburg III. From times before Ludwigsburg to year 1816). Ungeheuer + Ulmer Medienhaus, Ludwigsburg, Germany.

Sting A (2005) Geschichte der Stadt Ludwigsburg III. Von 1945 bis zum Schlossjubiläurm 2004 (History of city of Ludwigsburg III. From 1945 to palace's anniversary 2004). Ungeheuer + Ulmer Medienhaus, Ludwigsburg, Germany.

Stuttgarter Zeitung (01.10.2017) https://www.stuttgarterzeitung.de/inhalt.stadtlabor-ludwigsburg-aktiveversuchskaninchen-im-staedtischen-labor.54b0132a-2b6c47af-908a-2730ee4d1cb1.html (accessed 11/01/2019).

World Commition on Environment and Developement (1987) Our Common Future. World Commition on Environment and Developement, Oxford, UK, p.40.

\section{Figures}

Figure 1 based on: Kurth D (2016)

Figure 2 based on: https://modelcityplus.com/mcplus/

Figure 3 based on: Stadt Ludwigsburg Referat für

Nachhaltige Stadtentwicklung (Ludwigsburg Municipality,

Department Unit for Sustainable Urban Development) (RNS) (2018)

Figure 4 based on: Stadt Ludwigsburg Referat für Nachhaltige Stadtentwicklung (Ludwigsburg Municipality, Department Unit for Sustainable Urban Development) (RNS) (2018)

Figure 5 based on: Altmann O (2018) 